\title{
Penjor in Hindu Communities: A symbolic phrases of relations between human to human, to environment, and to God
}

\author{
Makna penjor bagi Masyarakat Hindu: Kompleksitas ungkapan simbolis \\ manusia kepada sesama, lingkungan, dan Tuhan
}

\author{
I Gst. Pt. Bagus Suka Arjawa ${ }^{1 *}$ \& I Gst. Agung Mas Rwa Jayantiari² \\ ${ }^{1}$ Department of Sociology, Faculty of Social and Political Sciences, Universitas Udayana \\ ${ }^{2}$ Faculty of Law, Universitas Udayana \\ Address: Jalan Raya Kampus Unud Jimbaran, South Kuta, Badung, Bali 80361 \\ E-mail: suka_arjawa@yahoo.com*\&gungmasjayanti@yahoo.co.id
}

\begin{abstract}
The purpose of this article was to observe the development of the social meaning derived from penjor (bamboo decorated with flowers as an expression of thanks to God) for the Balinese Hindus. In the beginning, the meaning of penjor serves as a symbol of Mount Agung, and it developed as a human wisdom symbol. This research was conducted in Badung and Tabanan Regency, Bali using a qualitative method. The time scope of this research was not only on the Galungan and Kuningan holy days, where the penjor most commonly used in society. It also used on the other holy days, including when people hold the caru (offerings to the holy sacrifice) ceremony, in the temple, or any other ceremonial place and it is also displayed at competition events. The methods used were hermeneutics and verstehen. These methods served as a tool for the researcher to use to interpret both the phenomena and sentences involved. The results of this research show that the penjor has various meanings. It does not only serve as a symbol of Mount Agung and human wisdom; and it also symbolizes gratefulness because of God's generosity and human happiness and cheerfulness. Penjor is a Tri Hita Karana (harmonious relationship between humans, humans with the environment, and humans with God) symbol.
\end{abstract}

Keywords: penjor; galungan; mecaru; odalan; Tri Hita Karana

\begin{abstract}
Abstrak
Tulisan ini bertujuan untuk memahami perkembangan makna sosial dari penjor dalam masyarakat Hindu Bali. Pada masa awal, penjor dimaknai sebagai simbol gunung agung, kemudian berkembang menjadi simbol kearifan manusia. Penelitian dilakukan di daerah Badung dan Tabanan, Bali dengan metode kualitatif. Penelitian ini tidak hanya dilakukan pada saat Hari Galungan dan Kuningan dimana penjor paling marak dipasang oleh masyarakat, tetapi juga pada hari raya lain, termasuk juga pada saat masyarakat Hindu Bali melaksanakan upacara pecaruan, odalan atau saat menyelenggarakan upacara lain sampai dengan acara perlombaan. Metode yang dipakai adalah hermeneutic dan verstehen, yaitu menafsirkan makna di balik peristiwa yang ada serta kalimat yang ada. Hasil penelitian menunjukkan bahwa penjor bukan sekedar simbol gunung agung, kearifan manusia,tetapi ungkapan terimakasih manusia kepada Tuhan atas segala rahmat yang diberikan dan yang paling akhir adalah dalam ucapan terima kasih itu juga sekaligus ungkapan kegembiraan. Penjor merupakan wujud simbolis Tri Hita Karana (hubungan harmonis antara manusia, manusia dengan lingkungan, dan manusia dengan Tuhan).
\end{abstract}

Kata kunci: penjor; galungan; mecaru; odalan; Tri Hita Karana

\section{Introduction}

The Balinese Hindu community has various rituals, and penjor has been one of the main decorations in those rituals. Penjor is a tall taped-poles made of bamboo, mainly displayed in Hindu holy day such as Galungan and Kuningan (Atmadja \& Atmadja 2016). At the celebration, the community installed penjor at the main door before the yard and at the edge of the gate where the prayers held. Penjor also installed in a religious ceremony at the temple (Input Bali 2015 \& Gama Bali 2019) and the mecaru ceremony (Purwandini 2012) and penjor also displayed to honor guests. In the past, penjor primary utilization was to decorate people's houses when King visited the rural areas. In modern times, the same rituals practiced in welcoming the official visit of Government elites. 


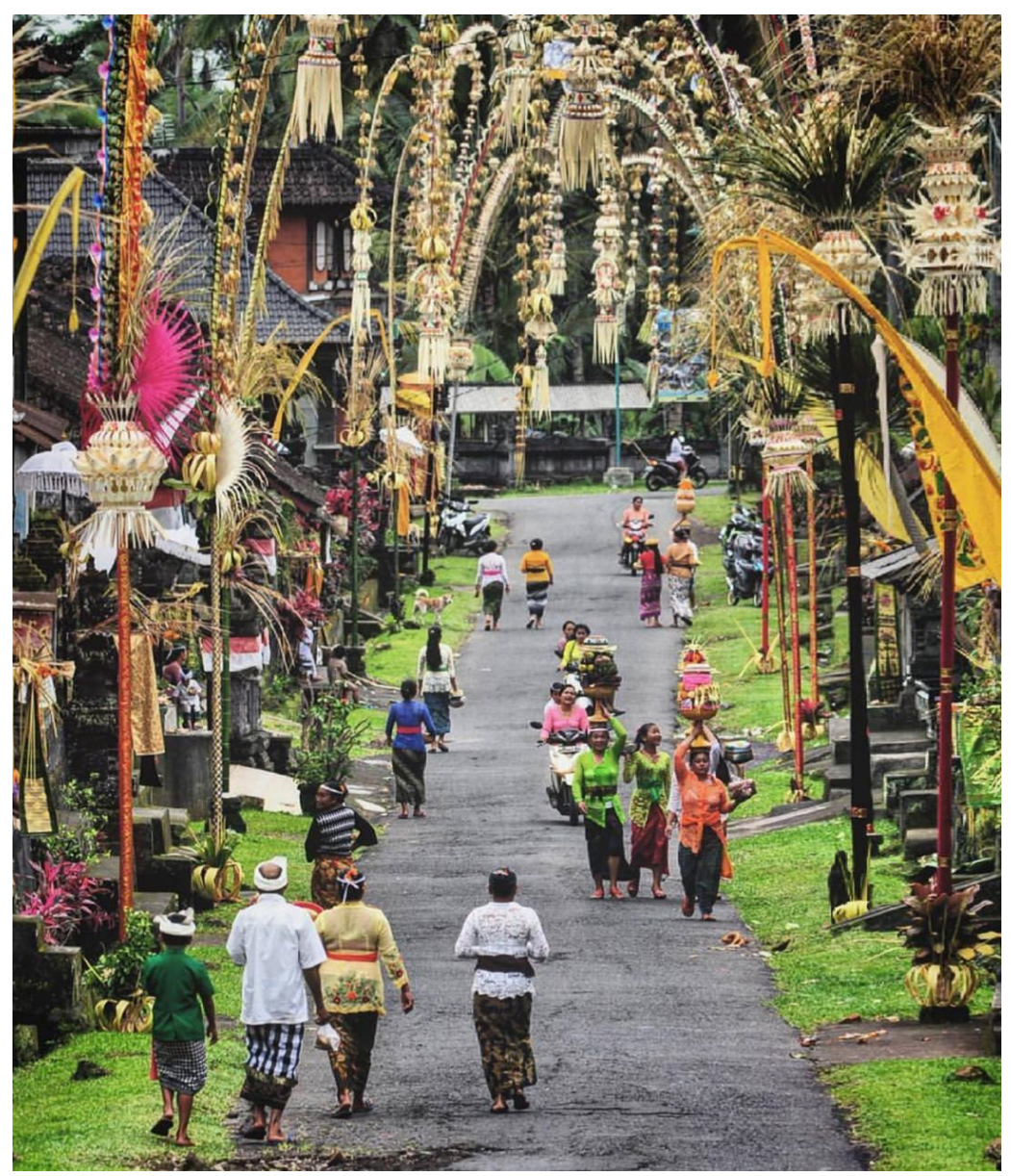

Figure 1.

Penjor in front of each resident's house during Galungan Day Source: Wiwoho (2019)

Aside from religious events and guests welcoming ceremony, penjor also installed at social events. Penjor also used as decoration and displayed during school grade promotion, university graduation, and during sports competitions. In various religious rituals and ceremonies, penjor always displayed in the primary position that highly visible to audiences. Balinese community also acknowledge penjor as the artistic activity by conducting a competition that emphasized the function of penjor as a creative process (Website Resmi Pemerintah Kabupaten Buleleng 2019). The form of penjor was developed according to the character of the area in Bali. It also related to the economic development of the region. In some areas, palm leaf only used in one level penjor while another area could use five to six young palm leaves. Nowadays, penjor made from palm leaves priced millions of rupiah.

Traditionally, the Balinese symbolizes penjor as Mount Agung (Brinkgreve 2016). Mount Agung is the highest mountain in Bali and the curved peak of penjor is likened the summit of Mount Agung. Pratama \& Marbun (2018) explained the meaning of penjor in social relations as the development of the real value as offerings or expressions of thanks to the earth for providing a place of life and human welfare. Penjor also perceived in realizing peace and human welfare to achieve the victory of dharma (good) against adharma (evil). Similar ideas, also revealed by Sumertini (2017), states that penjor is an expression of gratitude and devotion to God for the prosperity that is bestowed upon humankind. Penjor composed by sugar cane, coconut, rice, Balinese cakes, and various clothing is an expression of prosperity bestowed from God Almighty.

Suardana (2016) complement the interpretation of penjor by discussing the element of human pride. Penjor is an expression of gratitude to God Almighty (Ida Sang Hyang Widhi Wasa) because, after the victory against adharma, humans regain their prosperity. He asserted that penjor also raises human humility after earning their welfare - human is likened as rice, the heavier it grows, the lower 
it gets. Atmadja \& Atmadja (2016) states that penjor is a form of visual expression of gratitude to God to earn a blessing for human for better welfare. Penjor becomes a symbol of prosperity that continues to flow and adequate in foods and clothing. Given the four writings, the researcher concludes that penjor is a symbol of an expression of gratitude to God for the welfare given to humankind. It is also an expression of humanity's gratitude for successfully winning the war between dharma and adharma. This meaning is expressed more often in penjor in Galungan and Kuningan. Penjor symbolizes human humility in achieving success in life, also to visually demonstrate gratitude to God in order to gain better welfare.

Given the definition from existing research, the meaning of penjor can be further developedespecially in social relations, relationships between humans, humans to the environment, and God. We support the definition by Atmadja \& Atmadja (2016), who noted that penjor is an expression of demonstrative visual prayer to God. In community relations, the demonstrative expression can also be applied more broadly. In the sociological context, other things can be seen from the appearance of penjor as a whole, especially as an expression of human sense for the presence of God in their social life.

\section{Research Method}

The research method used is interpretation or hermeneutics and verstehen (in Deutsch; means to interpret). This method enables the researcher to interpret the phenomena that lie behind the appearance of an object or statement. This research was conducted in Badung and Tabanan Regency using a qualitative method. The method employs to overcome the obstacle for researchers to find scientific references regarding penjor. However, references to penjor are still used in this paper. Researchers employ the hermeneutic method to interpret phenomena observed in penjor and all its equipment. Hermeneutics is a method to analyze the meaning of a thing. Initially, this method was used to analyze the interpretation of the scriptures. It was further developed into the interpretation of phenomena in the world of literature, culture, politics, and philosophy. Subsequently, hermeneutics was used to interpret signs, symbols, religious rituals, artwork, history, literature, and psychology (Bakta 2018). Hermeneutics is a system of interpretation of the content and hidden meanings; in this case, the object is a social phenomenon (Bakta 2018). Ricoeur in Wachid (2006) states that all human life is dealing with language, even visually displayed art can be interpreted into language. Penjor is a form of culture of the Balinese Hindu Society which has artistic value and also has a complexity of meanings on various elements attached to it. Thus, penjor is an artwork that is visually displayed, can also be seen as a language for further interpretation.

Humans make penjor as a cultural expression with a particular symbol and value for social interaction. Blumer et al. in Ritzer \& Goodman (2007) stated that meaning and symbols enable humans to interact. They also added that humans could change the value and symbols they use in actions and interactions based on their interpretation of the circumstances. In the Balinese Hindu tradition, various symbols serve as a medium to get closer to God (Widana 2017). The researcher analyzed penjor using the verstehen method; this method designed for human action and interaction. Comte in Abel (1948) stated that verstehen is a method for interpreting human behavior. Sholikah (2017) stated that verstehen is a cognitive process of understanding which also includes the complexity of a human being, understanding expressions, and life experiences. Sholikah (2017) added that human activities are not only bound by consciousness but are also driven by goals that arise from the interpretation of situations and appreciation of values.

Penjor is a text with various symbols attached to it. Text is a method to express an event communicatively. Permadi (2000) stated that according to the content, the text could provide the narrative of people's daily life, including social, economic, cultural, governmental, political aspects. Text is a flow of ideas, discourses, author's reflection toward a phenomenon. Thus, penjor is an interpretative sentence for social interaction tools.

\section{Result and Discussion}

Penjor is a simple decorating building with a curved bamboo peak on the top. Penjor comes from the word 'enjor' the Balinese language, which means appearance (Suardana 2016). In the Balinese 
language, the word penjor means to show. Balinese people use the word 'enjor' to refer something arrogant or a situation to show. Wirta (2017) mentions that the origin of penjor is penyor, which has the intention to describe devotion or worship God.

Penjor designed according to the following structure: various accessories installed on the bamboo stems with the main element of is accessories made from young palm leaves. These yellow leaves are looped and attached to the bamboo stems - called bakang-bakang, other elements attached to penjor are agricultural products such as nutmeg, fruit nutmeg, and tubers. Penjor also contains human-made products such as traditional cakes. At the end of this, bamboo is a circle called tamiang functioned as a shield. In some places in Bali, tamiang also called sampyan. The bottom of penjor decorated by a tied plawe leaves. Plawe leaves are commonly used as a ceremony instrument. For the past decade, penjor experienced rises in sales in the market- penjor maker added a fabric written the words of Om Kara to symbolize God. Balinese people place penjor in their front yard. In religious ceremonies, the right side of penjor is an instrument to put offerings called sanggah. Penjor is a tall taped-poles made of bamboo that has been attached as social traditions of the Hindu Community in Bali. In general, the Balinese Hindu community installs penjor at the Galungan and Kuningan festivities, but the use of penjor is not only done on certain feasts. Penjor also used on other important days for the Balinese community.

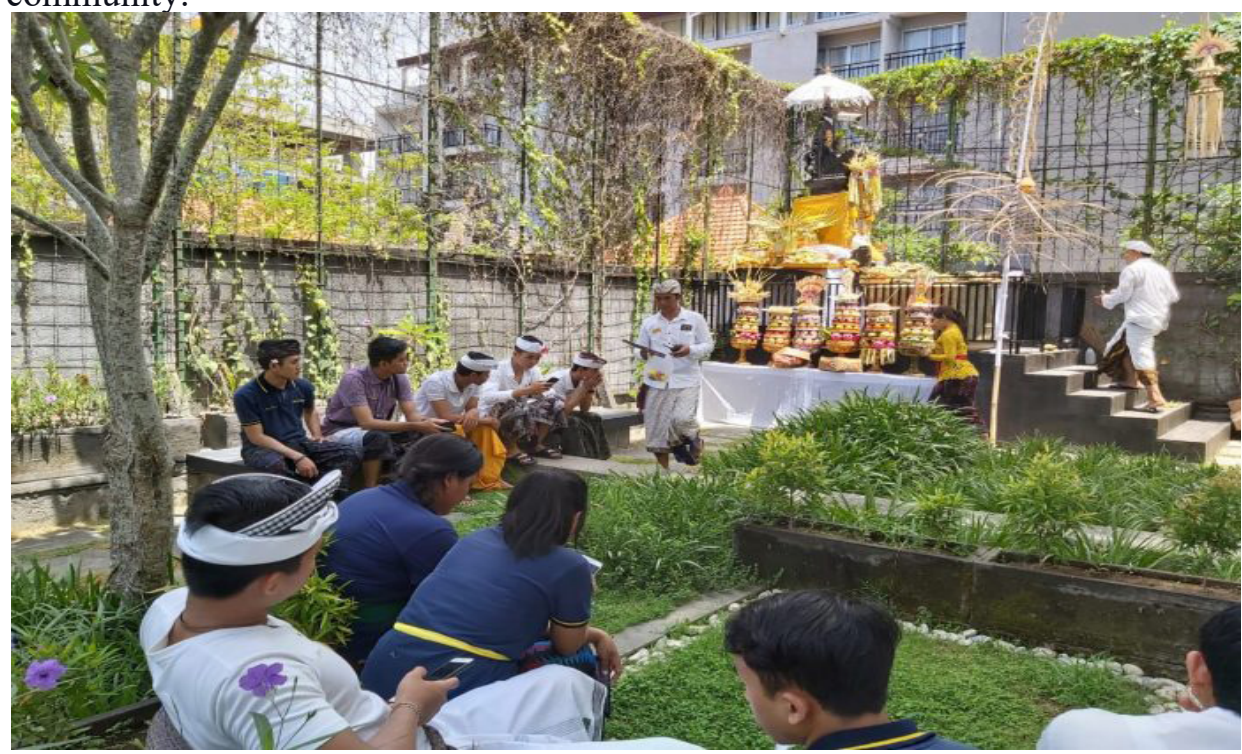

Figure 2.

In this ceremony, used the simple penjor.and installed in front of the monument (in the language of the Balinese Hindu community, called Padma).

Source: Bali Insipirasi (2019)

In the Balinese Hindu, symbols are an inseparable part of religion derived from various existing rituals. Religious rituals often utilize a particular medium to connect humans and their creators through religion. Rachmawati (2017) mentioned that ritual has a function to form a sense of solidarity. They attributed to various symbols in the ritual that can be proposed as an effort to express shared feelings. These symbols are highly attached to religion and deeply believed by the community. In every Hindu ceremony in Bali, the presence of symbols are definite. Given the context, penjor consists of a message to express human gratitude to God. This phenomenon supported by Geertz in Lubis (2015), which states that religion is a system consists of symbols that establish feelings and motivations, thorough, and preserved in humans by formulating conceptions about specific general laws (order), related to human's existence which further reflected reality. The Hindu priest, Dhaksa Dharmita (2015), stated that through a constitutive and characterized symbol, humans are reminded continuously with sacred elements in religion, worshiped, and glorified by the priest.

\section{Penjor interpretation in Galungan and Kuningan feast celebration}

Galungan is a memorial day to celebrate the victory of dharma in facing adharma. Dharma is good deeds performed by human beings; on the contrary, adharma is evil behavior. The Hindu community 
in Bali, celebrate this as a day to commemorate the victory. This celebration continues until Kuningan, ten days after Galungan. On Galungan and Kuningan holy days, the Hindu community in Bali and other Hindu communities in Indonesia with social roots from Bali will install penjor to celebrate the feast. Penjor installed at the entrance of the house or the yard. In urban housing, penjor will be installed in front of the entrance.

On Galungan, especially in Bali, people will slaughter pigs to process them into various types of food. They will give the food to the neighbors. In the $70 \mathrm{~s}$ and $80 \mathrm{~s}$, the Balinese provided a punjung, a traditional gift to congratulate the community who held a marriage ceremony. The gift symbolizes wishes that the wedding will be successful in facing many challenges in life. On Galungan and Kuningan, the Balinese Hindu community will pray in their place, starting from the Khayangan Tiga Temple, the Family Temple, to the Rong Tiga prayer center (a temple to worship Lord Brahma, Vishnu, and Siwa). They carry offerings that set up next to the penjor. Thus, Galungan can be interpreted into three aspects, namely 1) victory, 2) expression of joy (a celebration by making various types of food and sharing the food with neighbors), and 3) a form of gratitude to God (worship). Penjor is a means to commemorate and to show the victory. Penjor is a symbol of victory, joy, and gratitude to God - where the victory has received protection from tamiang, the symbol of protection which installed on Kuningan day.

\section{The Odalan's penjor}

Every six months (Balinese calendar/210 days) or a full year ( 2 x 210 days), Balinese Hindus celebrate the day of the establishment of temples, worship places owned by family or the community. This celebration is called Odalan. Odalan is a memorial day for temples or places of worship. The prayer located in the Khayangan Tiga, a place in the village to worship Lord Brahma, Vishnu, and Shiva or temples, belongs to organizations such as subak (rice field irrigation organizations in Bali) or sekhe (groups or organizations in general). Odalan also often referred to as petirtaan, petoyan, pujawali, or rainan (Pesona Indonesia 2018).

During Odalan, the Balinese decorated ornaments in the temple and installing penjor with the same patterns when celebrating Galungan and Kuningan at the entrance of the temple area. The temples in Bali, especially for Khayangan Tiga, have three parts, namely 1) outer jaba (outermost area), 2) middle jaba (middle area), and 3) jeoran (central prayer place). Penjor installed at the entrance to the outside jaba and jaba middle. It has become a tradition for the community to place one penjor at each entrance. However, in other traditions, penjor installed in a pair at each entrance. Odalan is a ceremony to express the gratitude of the people to God (Ida Sang Hyang Widhi Wasa) for the gift and grace given by Him. The Balinese Hindu community performs this ritual happily by bringing various offerings such as fruits, meat, and cakes. Offerings are placed in a container or arranged like a mountain form called gebogan. Offerings consist of natural products that also hung on penjor. It indicates that the Balinese Hindu Society has a close relationship with nature. According to Januariawan (2019), the earth is likened to a mother who feeds her children. In the celebration, the community sings various spiritual songs, wasps gongs, decorated ornaments, and buildings, also offering various offerings in others according to their possessions. The phenomenon of wearing white clothes emerged from the $80 \mathrm{~s}$. Prior to that, people used the newest clothing and accessories to go to the temple. It symbolizes the atmosphere of community excitement on the day.

It can be concluded that the ritual of Odalan has two elements, namely 1) excitement (shown with spiritual songs, gongs, jewelry in the temple building, and new clothes), and 2) Expressions of gratitude to Ida Sang Hyang Widhi Wasa (shown in prayers, thanksgiving for welfare which is a blessing from God) which manifested in the fruits, meat, and cakes. The combination of the two elements shows a victory for the community in celebrating their social life.

Penjor is an expression of joy, gratitude to God for the gifts given, and the symbol of victory. In the Village of Kemoning, Pupuan, Tabanan, the community called penjor as penjor bah, derived from the word rebah or collapsed. Penjor bah is similar to penjor in general in the aspect of materials and 
equipment but differs in the installation, and $2 / 3$ part of the stem is lying transversely at the entrance of the yard. Another instrument for the celebration is percangkor, made of bamboo, which has a smaller and shorter height compared to penjor in Galungan-Kuningan. The community made penjor bah about three weeks before the simultaneous ceremony in three significant temples in Kemoning Village. This ceremony takes place every five years, and the community welcomes the moment with enthusiasm and excitement. The community will focus their mind and energy on cooperating with other members in carrying out a big ceremony. Ahead of the ceremony, the Kemoning Village Community performed a Nyepi ritual. Penjor installed in front of the entrance of the house yard with a partially collapsed position. In this context, penjor interpreted as a symbol of the prohibition of entering the yard during Nyepi. However, the bakang-bakang decoration of young palm leaves, hanging nutmeg, nutmeg bunk (crop yields), and processed food products installed in penjor can be interpreted that the community is grateful to God (Ida Sang Hyang Widhi Wasa) for the grace given. It also symbolizes the joy before the coming of the big holiday (Odalan) in the village.

\section{Penjor manusia yadnya}

Another penjor functionality is during the Manusia Yadnya ceremony, a ritual of tooth filing, and marriage. In this ceremony, penjor is not complemented by sanggah or various other equipment such as fruits. Penjor is functioned as a decoration (Pratama \& Marbun 2016). Tooth filing ceremony intended to release the evil character on the human being such as anger and greed. Releasing such behavior will help humans to achieve balance and victory in defeating evil intentions. Likewise, with marriage, it is essential to maintain a balance between husband and wife in order to continue the descent. The formation of a new family is happy for humankind that should be celebrated. In various cultures, the marriage was celebrated with merrily. In the ceremony, penjor intended to welcome the joy of the new family, as an expression of happiness, and to welcome victory at the tooth filing ceremony.

\section{Bhuta yadnya penjor}

The mecaru ceremony is part of the Bhuta Yadnya (sacred sacrifice for the creature for the inhabitant of the non-human world) in Balinese Hindu rituals. In mecaru, there is an event to offer sacred sacrifice animals to the Balinese Hindu community. The ceremony carried in several places, such as in the yard or in the fields. According to Sumadi (2011), mecaru is a ceremony to avoid threat and disturbance from an evil force called Bhuta Kala. Mecaru is also carried out at crossroads or in other strategic areas. The purpose of mecaru is to achieve a balance between the human world and the underworld outside human life. Achieving this balance is a victory and joy for the people- as an effort to eliminate interference from the non-human world. According to the Old Javanese language, "caru" means sacrifice and the word "car" means balance. In the Swara Samhita book, "caru" can be interpreted as something harmonious and beautiful (Chasanah 2018). Widnyana et al. (2017) stated that the aimed balance is related to Tri Hita Karana, the belief of the Balinese Hindu community between humans and nature, with other humans, and with God. Therefore, beauty becomes one of the elements of "caru" ritual.

There are three elements set as goals for the Balinese Hindu community in holding mecaru ceremony, namely 1) natural balance, 2) harmony, and 3) beauty. Thus, the element of natural balance reflected on community harmony and excitement that represents human's victory- this is worth celebrating. Penjor's position and presence is a symbol of victory and joy for the community. The public can always enjoy the joy and victory, and a form of gratitude for the condition can be seen from the rituals and offerings of prayers that are recited during the mecaru ceremony.

\section{Penjor in a public ceremony}

Penjor also highly used as decoration in a public ceremony in Bali, such as class promotion and sports events. In this celebration, penjor located in a strategic position that visible for the audience. Classes promotions, graduations, and sports competitions are events that illustrate the atmosphere of 
excitement and victory. In the various type of competition, chasing a victory will give an atmosphere of pleasure. Thus, the presence of penjor symbolizes joy and victory. Penjor delivers messages to the community to be optimistic preserve happiness. The decoration attached to penjor is an expression of the person, family, or community that creates it. In Tegallalang Village, Gianyar, Bali, penjor is also used in the tradition of ngerebeg (traditional ceremony), an expression of excitement for teenagers before the religious ceremony made by snake fruit tree branches or palm wrapped around the ends of the penjor (Karma 2017).

The Christians Balinese that located in Dalung Village, Badung Regency and Palasari Village, Jembrana Regency use penjor during the Christmas and New Year holidays. Penjor has the same material and shape as the Balinese Hindu penjor. It was made of bamboo with curved peak at the end, complemented with bakang-bakang, sampian, and agriculture products on the penjor body. People in Dalung Village make a different type of penjor. It has no sanggah to be planted next to the penjor. In Canggu Village, Northern Kuta, with half of the population is Christian, penjor is installed in front of their houses and Churches (Suyatra 2017). Penjor installation is an uptake of Balinese Hindu culture, and this starts from those in the Bali Hindu Community. Penjor installed by the Christian Society is a symbol of victory and excitement for Christmas and New Year. Christmas is a celebration of the birth of Jesus Christ, considered as the day of victory and joy for the Christian Community. New Year is a day of welcoming a new atmosphere that celebrated happily by the community.

\section{Interpretation of penjor physical form}

The physical embodiment of penjor can be interpreted from the social side. Penjor installed in the open space. When the wind blows, penjor will sway and wave with its adornments. Penjor appearance is similar to a human who moves to express excitement. In an open space, joyful movements reveal messages to those who see penjor. It means that humans are happy and thankful for the various celebrations they had. The embodiment of penjor looks lively with adornment attached as an expression of human excitement. Bamboo rods are medium to express messages of joy to others. Bamboo trunks with various decorations are flexible and graceful, and it dances when the wind blows. Penjor in the wind looks like a person who screams, raises hands, and runs happily. Fruits, tubers, and processed human products installed on the penjor is a symbol of success and gratitude. The integral component is the result of earth and human creativity. The composition symbolizes the success of humans to process agricultural products. Therefore, penjor also displayed as the exhibition of community agricultural products and appreciation for the abundant harvest. Bhagavad Gita IX: 26 said:

"Whoever bows down to offer me leaves, flowers, fruit, or water with all my heart, love offerings, offerings from pure hearts that I will accept."

In worshiping God, make an offering through their achievement on earth. Offerings can be composed through simple thing; quoting the sloka as mentioned earlier verse: fruits, tubers, and processed products of humans in penjor is the embodiment of human as a creative creature with the ability to think and to work in the world and worship the God (Ida Sang Hyang Widhi Wasa). The offering is a form of devotion and gratitude to God for the abundance of grace given.

Sanggah installed side by side with penjor, symbolizes the diety and gratitude to God. Through prayer, the community connects the work in the earth, such as agricultural products in penjor as evidence of success as well as offerings. Nowadays, people put white and yellow cloth labeled $\mathrm{Om}$ Kara in penjor body, a Sanskrit letter that symbolizes God. According to Latra et al. (2015), Indians and East Asians uphold pantheism that regards God can be found everywhere in the universe. Balinese Hindu also holds the same perspective, and it is apparent in penjor with its equipment. Nowadays, the installation of white and yellow cloth on penjor is excessive because objects installed in sanggah installed next to penjor has shown humanity's service to God (Ida Sang Hyang Widhi Wasa).

\section{Conclusion}

Aside from symbolizing gratitude to God for the victory of dharma against adharma and for the prosperity that God has given to humans through harvest and human labor, penjor has a broader 
message to the surrounding community. Penjor visually embodies the expression of human excitement. All ceremonies that use penjor as a means have a meaning of joy or something worth celebrating pleasantly. The expression of joy is visually expressed not only to God but also to members of the community. It is the reason penjor installed in front of the house. People share the joy of victory at Galungan and Kuningan. The social message of expressions of joy is also seen at the time of the celebration, celebrating a class promotion, competitions in sports, and other events.

Society uses penjor as an embodiment of prosperity that they achieved. It is an expression of gratitude to God. Relationships between humans can be seen from the symbolic interaction through the installation of penjor in front of the house during Galungan and Kuningan. The relationship between humans and nature and the environment can be seen from the agricultural products tied to penjor as visualization of personal success to preserve the environment. The relationship between humans and God can be seen from the expression of gratitude manifested by the cloth of Om Kara attached to the penjor stem, including the sanggah beside the penjor. It can be concluded that penjor is a symbolic complexity that implies a human relationship with humans, with nature, and with God.

\section{References}

Abel T (1948) The operation called verstehen. American Journal of Sociology 54 (3) [Accessed 15 June 2019] 211-218. https://www.jstor.org/stable/2770547.

Atmadja AT \& Atmadja NB (2016) Kontestasi penjor Galungan-Kuningan di Bali visualisasi doa petisi secara demonstratif untuk kemakmuran pada era Masyarakat Tontonan. Jurnal Kajian Bali 6 (2):159-176.

Bakta IM (2018) Pengantar Filsafat Ilmu. Denpasar: Udayana University Press.

Bali Inspirasi (2019) A Celebration to Commemorate its Temple's Fifth Anniversary [online] [Accessed 12 April 2020]. https://baliinspirasi.com/piodalan-at-citadines-kuta-beach-bali-acelebration-to-commemorate-its-temples-fifth-anniversary.html.

Bhagavad Gita, Conversation IX:26. Rajavidya Rajaguhya Yoga. [Accessed 15 June 2019]. https:// bhagavadgita.or.id/percakapan-9/.

Brinkgreve F (2016) Lamak: Ritual objects in Bali. Dissertation, Leiden University, Leiden. [Accessed 15 June 2019]. https://openaccess.leidenuniv.nl/bitstream/handle/1887/45614/ 02.pdf? sequence $=5$.

Chasanah NL (2018) Makna Upacara Caru Panca Sata bagi Umat Hindu di Pura Agung Jagat Karana, Kecamatan Krembangan, Surabaya.Thesis, UIN Sunan Ampel, Surabaya. [Accessed 2 March 2019]. http://digilib.uinsby.ac.id/23241/.

Dharmita IPMSBD (2015) Sosiologi Majelis Hindu: Titik Awal Reformasi Menuju Masyarakat Egaliter, Awas Statu Quo Bangkit. Surabaya: Paramita.

Gama Bali (2019) Makna dan Pesan dalam Penjor Galungan. [Accessed 12 April 2020]. https:// gamabali.com/makna-dan-pesan-dalam-penjor-galungan/.

Input Bali (2015) Filosofi dan Arti dari Unsur-Unsur Penjor Galungan. [Accessed 12 April 2020]. https://inputbali.com/budaya-bali/filosofi-dan-arti-dari-unsur-unsur-penjor-galungan.

Januariawan IG (2019) Lingkungan hidup Desa Pakraman Panglipuran: Kajian teologi Hindu. Jurnal Penelitian Agama Hindu 3 (1):63-74. [Accessed 15 June 2019]. https://ejournal.ihdn.ac.id/ index.php/JPAH/article/view/818/677.

Karma MP (2017) Penelusuran nilai tangible dan intangible heritage dalam Tradisi Ngerebeg di Desa Tegallalang, Gianyar Bali. In: Prosiding Seminar Haritage IPLBI. [Accessed 3 November 2019]. https://doi.org/10.32315/sem.1.b103.

Latra IW, Surpa IW, Suryani IGAP, Karda IM, \& Harsana IKG (2015) Pendidikan Agama Hindu dalam Membangun Karakter Bangsa. Denpasar: Universitas Udayana.

Lubis RHM (2015) Sosiologi Agama: Memahami Agama dalam Interaksi Sosial. Jakarta: Kencana. 
Pratama KHS \& Marbun S (2016) Komodikasi penjor sebagai sarana persembahyangan Umat Hindu. Jurnal Studi Kultural 1 (2):110-115.

Permadi T (2000)Teks, Tekstologi dan Kritik Teks. [Accessed 3 November 2019]. http://file.upi.edu/ Direktori/FPBS/JUR._PEND._BHS._DAN_SASTRA_INDONESIA/197006242006041TEDI_PERMADI/Teks\%2C_Tekstologi\%2C_dan_Kritik_Teks.pdf.

Pesona Indonesia (2018) Piodalan, Tradisi Peringatan Lahirnya Pura. [Accessed 23 April 2019]. https://pesona.travel/keajaiban/374/piodalan-tradisi-peringatan-lahirnya-pura.

Purwandini P (2012) Penjor sebagai kearifan lokal. 29 May 2012. Piyan Purwandini: Blog [Accessed 12 April 2020] http://piyanpande.blogspot.com/2012/05/penjor-sebagai-kearifan-lokal.html.

Rachmawati DK (2017) Kearifan lokal dalam leksikon ritual kesenian ogoh-ogoh di Pura Kerthabumi, Dusun Bongso Wetan, Desa Pengalangan, Kecamatan Menganti Kabupaten Gresik, Jawa Timur. PAROLE: Journal of Linguistics and Education 5 (2):129-144.

Ritzer G \& Goodman DJ (2007) Teori Sosiologi Modern. Jakarta: Kencana Prenada Media Group.

Sholikah (2017) Pemikiran hermeneutika Wilhelm Dilthey (1833-1911 M). Jurnal Studi Keislaman 7 (2):109-120. http://ejournal.kopertais4.or.id/pantura/index.php/alhikmah/article/view/3285.

Suardana JM (2016) Arti dan makna penjor sesungguhnya. 7 February 2016. Pasraman Sesepuh: Blog [Accessed 11 March 2019] http://pasramansesepuh.blogspot.com/2016/02/arti-danmakna-penjor-yang-sesungguhnya.html.

Sumadi K (2011) Upacara Rsi Gana Agung: Kearifan lokal Bali menjaga harmonisasi hukum alam semesta. Vyavaharaduta 5(1)

Sumertini IW (2017) The dynamics of Galungan Day for Hindus in globalization era. International Journal of Advanced Multidisciplinary Research 4 (12):57-64.

Suyatra IP (2017) Natal di Bali; Ada Gebogan, Penjor, Hingga Pakaian Adat Bali, Bali Express, 26 December 2017. [Accessed 28 March 2020]. https://baliexpress.jawapos.com/read/2017/12/ 26/35771/natal-di-bali-ada-gebogan-penjor-hingga-pakaian-adat-bali.

Wachid ABS (2006) Hermeneutika sebagai sistem interpretasi Paul Ricoeur dalam memahami teksteks seni. Imaji 4 (2):198-209. https://doi.org/10.21831/imaji.v4i2.6712.

Website Resmi Pemerintah Kabupaten Buleleng (2019) Lomba Penjor Hias, 44 Peserta Antusias Ikuti Perlombaan. [Accessed 12 April 2020]. https://bulelengkab.go.id/detail/berita/lombapenjor-hias-44-peserta-antusias-ikuti-perlombaan-76.

Widana IGK (2017) Pemanfaatan simbol suci Hindu dalam industri pariwisata Bali. Dharmasmrti: Jurnal Ilmu Agama dan Kebudayaan 16 (1):102-110. https://doi.org/10.32795/ds.v16i01.79.

Widnyana IK, Raka DN, \& Javandira C (2017) Caru Kearifan Lokal "Tinjauan Manfaat dalam Kesuburan dan Biodiversitas Tanah”. Denpasar: Universitas Mahasaraswati Press.

Wirta IW (2017) Komodifikasi penjor Galungan sebagai media komunikasi di Banjar Adat/Pakraman Siladan, Desa Tamanbali, Bangli. Vidya Samhita: Jurnal Penelitian Agama 3 (2):41-62.

Wiwoho AI (2019) Rahajeng Rahina Galungan lan Kuningan, Semeton Bali [online]. [Accessed 12 April 2020]. https://www.instagram.com/p/B0TMcIdgT5n/. 